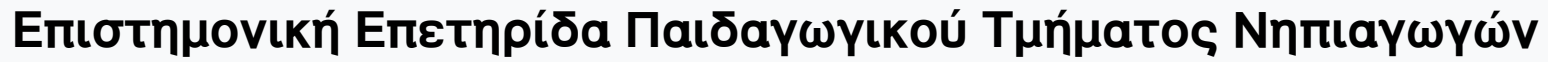

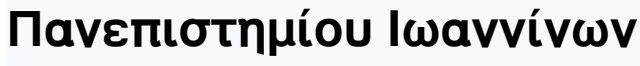

Tóp. 9, Ap. 1 (2016)

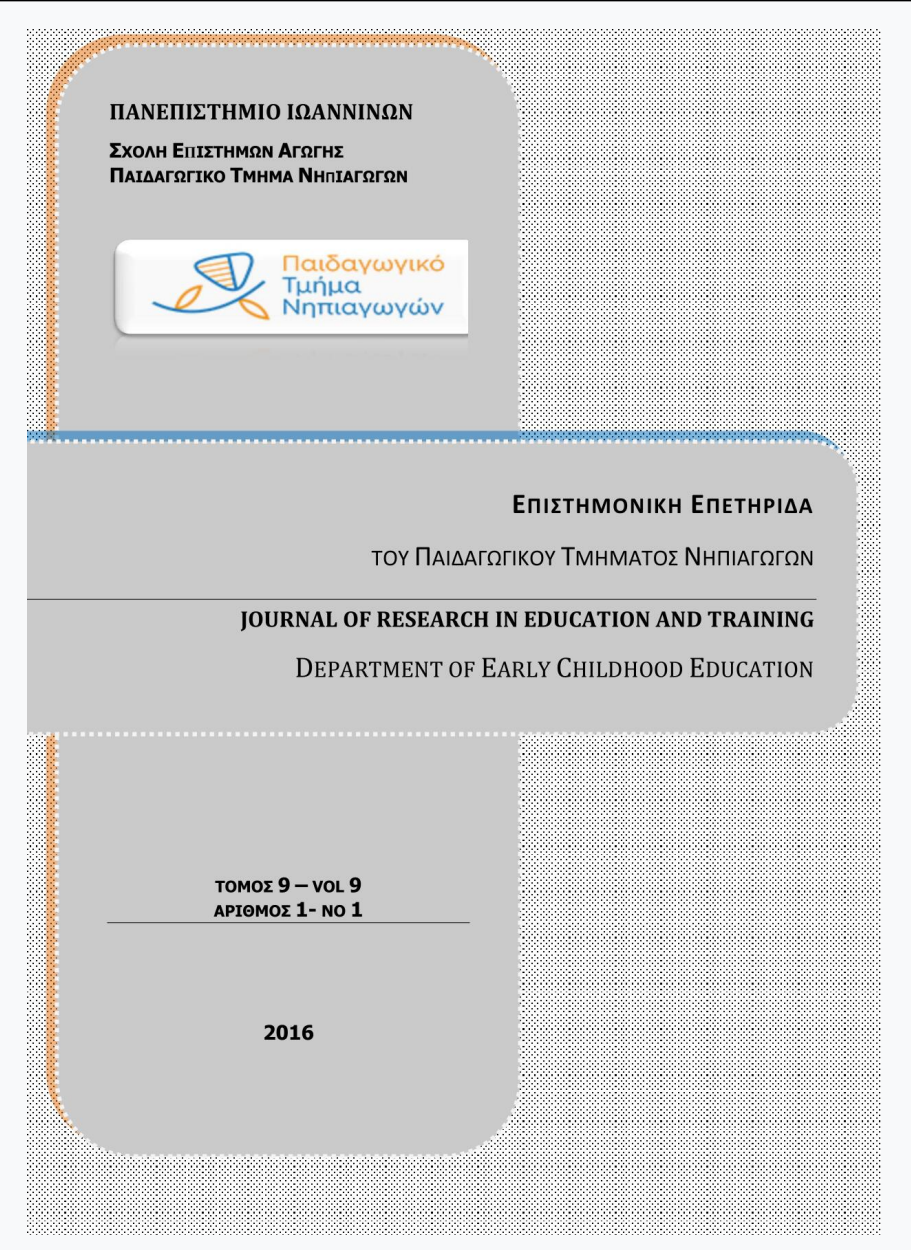

\begin{abstract}
A Reflection of the Global History: The Persian Empire's Role in the Relations between the Roman Empire and China (1st - 7th century CE )
\end{abstract}

QIANG LI

doi: $10.12681 /$ jret.8697

\section{Copyright @ 2016, QIANG LI

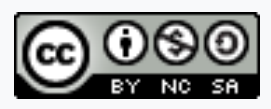

Aঠ¿ıа Xpńбnৎ Creative Commons Attribution-NonCommercial-ShareAlike 4.0.

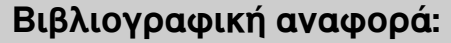

LI, Q. (2016). A Reflection of the Global History: The Persian Empire's Role in the Relations between the Roman Empire

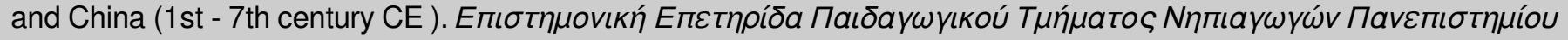

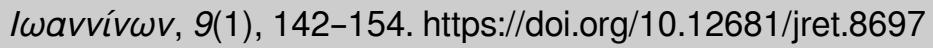




\title{
A Reflection of the Global History:
}

\section{The Persian Empire's Role in the Relations between the Roman}

\section{Empire and China $\left(1^{\text {st }}-7^{\text {th }}\right.$ century CE $)$}

\author{
Qiang Li \\ School of History and Culture, Northeast Normal University, China
}

Written sources, epigrams and archaeological evidence (fig. 1 and fig. 2) from the Eurasian continent in several languages support that Chinese and the Roman Empire kept long-term communication in different ways, such as trade, culture, religion, diplomacy etc. It is sure that this kind of interaction was achieved through the network of the famous Silk Road. However, in consideration of their locations, there was hardly direct and smooth communication between them because of the obstacles of the intermediate countries which were on the Eurasian Steppe between them. According to Chinese sources, from the western side, "The King of Daqin (the Roman Empire) wanted to get in touch with Han Dynasty of China, but the Parthia (Anxi) wanted to sell them Han silk in the sea, hence, because of the obstacle of the Parthia, they (Romans) could not arrive in China" (Hou Hanshu-Xiyu Zhuan) ${ }^{1}$; from the eastern side, it is also recorded in the same source that, in $97 \mathrm{CE}$, a Chinese envoy Gan Ying, who was sent to visit the Roman Empire (Daqin), was stopped by the sailors living on the west border of the Parthia (Anxi). They told him that it was difficult to travel through the West Sea to the Roman Empire, for which reason Gan Ying could not continue. ${ }^{2}$ Through research, it has long been concluded that Daqin is

This paper is based and enlarged on the subchapter (2.3) of my dissertation "Relations between the Roman Empire and China: On the Image of the Roman Empire in Chinese Sources from the Third Century CE to the Seventh Century", Ioannina, 2015.

${ }^{1}$ Hou Hanshu (Standard History of Later Han) was compiled by Fan Ye (398 -445 CE). It covers the history of the later Han Dynasty from the years 25 to 220 CE. Ye Fan (2014), p. 2920. English version in Vol. 88, HHS, Zhi-qiang Chen (2004), p. 272; Tai-shan Yu (2013), pp. 72-73.

2 "In the ninth year of the Yongyuan reign-period of Emperor He (the year 97), the Protector General, Ban Chao, sent Gan Ying as an envoy to Daqin. He arrived at Tiaozhi, overlooking the great sea. When he was about to take his passage across the sea, the sailors of the western frontier of An-xi told [Gan] Ying: "The sea is vast. With favorable winds it is still only possible for travelers to cross in three months. But if one meets with unfavorable winds, it may even take two years. It is for this reason that those who go to sea always take on board three years' provisions. There is something in

Correspondent Author: Dr. Qiang Li

Department: School of History and Culture, University: Northeast Normal University, China e-mail: 109024767@QQ.COM e-publisher: National Documentation Centre, National Hellenic Research Foundation URL: http://ejournals.epublishing.ekt.gr/index.php/jret/index 
the Roman Empire ${ }^{3}$ and Anxi is the Parthian Empire ${ }^{4}$. Hence, Both the information for both sides suggests that the Persians were the main obstacle between the communications of China and the Roman Empire at least during the first century CE. Figuring out the role of the Persian Empire is crucial to the understanding of the interaction between China and the Roman Empire. In this paper, through analyzing the sources in different languages and latest archaeological evidence, with focus on the Chinese sources from 1st to 7th century $\mathrm{CE}$, the role of the Persian Empire between the two empires and its relation with them will be explored.

Before the coming of the Industrial Age, communications between the Greco-Roman world and Asia (even around the world), which were connected by the Eurasian Steppe, were rare and difficult to realize. Even though there existed few examples of direct communications (mostly happened in later time of the Medieval Ages), which were realized through years, for the most part of the history, the communications were indirect, and realized through intermediaries. The intermediaries, especially those who lived in strategic regions, controlled the communications between the two civilizations as they wanted or needed, either promoting or blocking them. ${ }^{5}$ During the first seventh centuries of the Common Era, between the Roman Empire and China, there were different peoples living on the Eurasian Steppe who played their roles as intermediaries, such as Arabs, Jews, Persians, Kushans, Turks, Sogdians, Indians, and Kunlun people (possibly living in Malaysia and the islands of Indonesia). These people were active in different periods and played an influential role in connecting the two sides of the Eurasian Steppe. During those times, they had close relations with the two great empires through wars, diplomatic and commercial activities, religions etc.

Regardless, with respect to the communications between the Roman Empire and China, the most influential and powerful intermediary for the longest period of time was the Persian Empire. ${ }^{6}$ During the aforementioned period, the Persian Empire went

the sea which is apt to make men homesick, and several have there thus lost their lives." It was when he heard this that [Gan] Ying gave up.", Ye Fan (2014), p. 2918. English version in Vol. 88. HHS, (2004), p. 274; Tai-shan Yu (2013), pp. 63-64.

${ }^{3}$ M. Kordosis (1991), pp. 181-205; Zhi-qiang Chen (1994), p.12; Xu-shan Zhang (2005), pp. 14-18; D. D. Leslie \& K. H. J. Gardiner (1996), pp. XVII-XXIV.

${ }^{4}$ Hirth (1885), pp. 138-141; E. Chavannes (1907), p. 177; D. D. Leslie \& K. H. J. Gardiner (1996), p. 251; Tao Wang (2007), p. 90 etc.

${ }^{5}$ Xu-shan Zhang (2012), p. 248.

${ }^{6}$ The high influence of Persian land to the world has been given such remark: As a power which dominated many lands, influenced many cultures, and was receptive in turn to their impact, the place of Iran in world history and its contribution to world culture can be understood only in the light of its exchanges with the societies and the friendly or rival powers which surrounded it. See E. Yarshate (2006), p. 480. 
through two important phases: the Parthian Empire and the Sassanian Empire, accordingly, their role and relations with the two empires will be analyzed through these two phases.

The Parthian Empire (fig. 3) was the inheritor of the powerful Achaemenid Empire, and it consisted of Iran and Mesopotamia for more than four and a half centuries (247 BCE- $224 \mathrm{CE}){ }^{7}$ Due to its advantageous and strategic position, it controlled firmly the routes connecting the Mediterranean Sea and the territories of the Roman Empire with Central Asia and China. ${ }^{8}$ The early kingdom of Parthians was set up in 247 BCE at the ancient city of Asaak in the southern borders of Caspian Sea. ${ }^{9}$ It is believed that by the middle of the second century BCE, the center of gravity of the Parthian Empire had shifted to Mesopotamia, and apart from occasional encroachment on one side or the other, the Euphrates formed Iran's western frontier until the end of the Sassanian period in the seventh century. ${ }^{10}$ Some scholar believes that from the end of the second to the beginning of the first century BCE (during the reign of Mithridates II, 124/388/87 BCE), the Parthian Empire formally emerged onto the international stage. ${ }^{11}$ During this time, Parthians succeeded in extending their rule into Armenia and Mesopotamia, ${ }^{12}$ which led them to be in contact with Rome. When Syria became a province of Rome in $64 \mathrm{BCE}$, the Parthian Empire directly met with the powers of the Rome. ${ }^{13}$ It has to be admitted that Parthians remained the greatest unconquered foes of imperial Roman Empire through most of its rule. In the following centuries, wars and treaties often happened between them. The result of this situation is that the extension of Rome to the east was blocked by the Parthian Empire, and the westward activities of the Parthian Empire were similarly stopped by Rome, so that the Euphrates River remained the long-term border between them. Apart form the military conflicts between them, the Parthian Empire also controlled the commercial activities of the Roman Empire on land with the Far East. The information given at the beginning of this paper provides us evidence of the block by Parthians of the silk

\footnotetext{
${ }^{7}$ Parvaneh Pourshariati (2008), p. 20.

${ }^{8}$ Leonardo Gregoratti (2015), p. 44.

${ }^{9}$ The early development of Parthians is presented in kinds of works, such as E. Yarshate (2006), pp. 2829; Parvaneh Pourshariati (2008), pp. 19-20.

${ }^{10}$ E. Yarshate (2006), p. 483.

${ }^{11}$ Beate Dignas \& Engelbert Winter (2008), p. 9.

${ }^{12}$ Arnaud (1987), pp. 129-146. Parvaneh Pourshariati (2008, p. 20) puts forward that as early as 140s, during the reign of the Mithridates I (or Mithradates I), the Parthian power in Mesopotamia was beyond doubt: by $141 \mathrm{BCE}$, Mithridates I's power was recognized as far as the ancient city of Uruk in Mesopotamia. Around this time, Mithridates I also conquered the important Seleucid city Seleucia, where he crowned himself king.

${ }^{13}$ Beate Dignas \& Engelbert Winter (2008), p. 12.
} 
trade of the Roman Empire with China.

The King (of Daqin) always wanted to enter into diplomatic relations with the Han. But the Anxi wanted to trade with them in Han silk and so put obstacles in their way, so that they could never have direct relations [with Han]. ${ }^{14}$

Because of the block on land, in the discussed period, the Roman Empire turned its attention and successfully opened the sea route to Indian and South China, directly touching the origin of the Chinese silk. Thus, to an extent, they break the monopoly of Parthians for raw silk in the first two centuries CE. ${ }^{15}$ Strabo mentioned that, by the time of Augustus, up to 120 ships were setting sail every year from Myos Hormos to India. ${ }^{16}$ The author of the Periplus of the Erythraean Sea tells us the bulk of the commodities sold by the Greco-Roman merchants in Barbaricum of India ${ }^{17}$. An envoy from Daqin recorded in Chinese sources is also such kind of clear evidence for the opening of the sea route by the Roman Empire, "until the ninth year of the Yanxi reign-period of Emperor Huan (the year 166), An Dun, King of Daqin, sent an envoy from beyond the frontier of Rinan (in nowadays Vietnam) who offered elephant tusk, rhinoceros horn, and tortoise shell. It was only then that for the first time communication was established [between the two states]"18. Apart from the written sources, archaeological evidence also provides us valuable testimonies about their communications through sea. Hoards of Roman coins have been found in southern India from the period of Roman-Indian trade. Roman objects have been found in India in the seaside port city of Arikamedu ${ }^{19}$, which was a center of trade during this era. ${ }^{20}$ Meanwhile, a few Roman coins seem to have been carried further east, and the contexts of these finds are not very clear. They include the well-known second century medallions of Marcus Aurelius and Antoninus Pius found at $\mathrm{Oc} \mathrm{Eo}^{21}$, a thirdcentury copper coin of Victorinus from U-Thong in Thailand, and another Roman

${ }^{14}$ Ye Fan (2014), p. 2920, English version in Vol. 88, HHS, Zhi-qiang Chen (2004), p. 272; Tai-shan Yu (2013), pp. 72-73.

${ }^{15}$ Xu-shan Zhang (2001), pp. 87-92.

${ }^{16}$ The Geography of Strabo, vol. 1, 2.5.12.

${ }^{17}$ Barbaricum or Barbarikon (B $\alpha \beta \beta \alpha \rho$ ikóv) was the name of a sea port near the modern-day city of Karachi, Sindh, Pakistan, important in the Hellenistic era in Indian Ocean trade.

${ }^{18}$ Ye Fan (2014), p. 2920. English version in Vol. 88, HHS, Zhi-qiang Chen (2004), p. 272; Tai-shan Yu (2013), pp. 72-73.

${ }^{19}$ Arikamedu is an archaeological site in Kakkayanthope, Ariyankuppam Commune, Puducherry, India. It was a trading port in the first century $\mathrm{AD}$, and many Roman artifacts have been excavated there.

${ }^{20}$ John Haywood (2000), p.46.

${ }^{21}$ It used to be a harbor and trade center in Southwest of nowadays Vietnam, where lots of products from the Greco-Roman world arrived here. For some scholars, it is believed to be the harbour known to the Romans as Kattigara, see W.J. van der Meulen (1975), p. 17. 
coin, too worn to be properly identified, found at Khuan Lukpad in Peninsular Thailand ${ }^{22}$ etc.

On the eastern side, the earliest information about the Parthian Empire in Chinese sources appeared in Shiji ${ }^{23}$ and $\mathrm{Hansh}^{24}$, which record the information given by Zhang Qian, who was on missions to the Western Regions ${ }^{25}$ and further. Apart from many detailed descriptions on the local conditions of the Parthian Empire, the first official diplomatic relation between the Parthian Empire and China was also written down:

Emperor Wu was the first to send envoys to Anxi. The king ordered a general to take a force of 20,000 cavalry to greet them at the eastern border. The eastern border is several thousand $l i$ distant from the king's capital. When in the course of a journey one is about to approach [the capital] one passes through towns which can be numbered in the tens, and where settlements are uninterrupted. [The king] took the occasion to send out [his own] envoys to come to Han in company with the Han envoys so as to observe Han territory. They took large birds' eggs and conjurors from Lijian as a present for the Han [emperor], and the Son of Heaven was delighted. East of Anxi is the Darouzhi. ${ }^{26}$

\footnotetext{
${ }^{22}$ Bérénice Bellina and Ian Glover (2004), p. 71.

${ }^{23}$ The Shiji (Records of the [Grand] Scribe) which was written by Sima Qiang, is a very famous universal history of early China and the first of the official dynastic histories. It is the first history of China written in a biographic-thematic style in which biographies of different type, treatises and tables are combined. The Shiji covers a very long time period, ranging from the mythological "Yellow Emperor" Huangdi (trad. r. 2697-2597 BCE), the Xia (17th-15th cent. BCE, trad. 22051766), Shang (17th-11th cent. BCE, trad. 1766-1122), Zhou (11th cent.-221 BCE, trad. 1122-221) and Qin (221-206 BC) dynasties down to the contemporary period. It ends in the year 93 BCE. The main focus is on the Warring States period (5th cent.-221 BCE) and the Qin and the Han dynasties, see http://www.chinaknowledge.de/Literature/Historiography/shiji.html, accessed to 05-11-2015.

24 The Hanshu written by Ban Biao, is the official dynastic history of the Former Han dynasty (206 BCE-8 CE). It is also the first history concentrating on one single dynasty.

25 The Western Regions, or in Chinese Xiyu, means the Western Regions, it is a term used in Chinese historical writings referring to the regions in Northwest China from the Han until the Qing Dynasties. Since in ancient China the territory in the west was frequently changing, neither were the referents of Xi-yu consistent. In consideration of the long period, generally, Xiyu has two referents: in the broad sense, it points to the vast western area outside of the Jade Gate of China; in a narrow sense, it only points to the southern part of the modern Xinjiang Province and Turfan and Hami, see Xin-jiang Rong and Xin Wen (2012), p. 113.

${ }^{26}$ Tai-shan Yu (2013), pp. 54-55. Darouzhi (大月氏, the characters in Pingyin system spell Dayuezhi, however, in ancient Chinese it was pronounced as Darouzhi) was an ancient Chinese tribe, who originally settled in the arid grasslands of the eastern Tarim Basin area, in what is today Xinjiang and
} 
This text informs that during the reign of Emperor Wu (157-87 BCE), a Chinese envoy was accepted by the king of Anxi, namely the Parthian Empire. Afterwards, the Anxi king sent his own envoy to China bearing a tribute along with the Chinese envoy in order to learn of the greatness of China. Since this event happened in the reign of Mithridates II, and it is known that Anxi is Parthia, it is assumed that the envoy from Parthia was sent by Mithridates II. ${ }^{27}$ Later on, from about 100 BCE until 87 CE, there is no mention in Chinese sources of any embassies from Parthia. Then, in 87, 94, and $101 \mathrm{CE}$, envoys from Parthia were again recorded. ${ }^{28}$ These recordings prove that, since at least the end of the second century BCE, the Parthian Empire had set up official relationship with China. Later on, in the first century $\mathrm{CE}$, official relations between them were very frequent. Based on the relations set up by embassies, commercial and cultural activities also flourished. ${ }^{29}$ Some scholars even propose that the embassies from Anxi in the first century stimulated the mission of Gan Ying to Daqin. $^{30}$

As the successor of the Parthian Empire, the Sassanian Empire (fig. 4) was set up in $224^{31}$. It is said that during the Late Antiquity, the Sassanian Empire was considered to have been one of Iran's most important and influential historical periods, and constituted the last great Iranian empire before the Muslim conquest and the adoption of Islam. ${ }^{32}$ Since the very beginning, the empire held hostility toward the Roman Empire. It established a formidable new power on the Roman Empire's eastern frontier, and relations between them over the next four centuries were neither smooth nor friendly. Considering their hostile attitude, the Roman Empire also viewed the

western Gansu, in China. In the second century BCE, defeated by Xiongnu, they moved west until Bactria. Later on, a group of them set up the Kushan empire (30-375), see Xin-ru Liu (2001), pp. 261-292.

${ }^{27}$ Yu Tai-shan (2013, p. 55) holds that the first envoy to An-xi from Han during the reign of Emperor Wu must have been the deputy envoy dispatched by Zhang Qian when he was on the mission to Wusun. Zhang Qian's mission to Wusun occurred early in the Yuanding reign period, and this deputy envoy must have reached An-xi in the first or second year of the Yuandiang reign period (116 or 115 BCE). At the time, Mithridates II's (c. 124/123 - 87 BCE.) attack against the Sakas was close to victory, and his army was gathered on the eastern border. It was probably because of this that Mithridates II sent a force of 20,000 cavalry to greet the Han envoy. This view is supported by a number of scholars, also see J. Thorley (1971), p. 71; Xu-shan Zhang (2012), p. 271.

${ }^{28}$ D. D. Leslie \& K. H. J. Gardiner (1996), p. 140.

${ }^{29}$ Through the abundant information on An-xi in written sources, Sun Yu-tang $(1978$, p. 10) considers that the communications in commerce and culture were .also very frequent.

${ }^{30}$ D. D. Leslie \& K. H. J. Gardiner (1996), p. 140.

${ }^{31}$ For the early history of the Sassanian empire, see Arthur Christensen (1939), pp. 109-110; Richard N. Frye (2007), pp. 464-467.

${ }^{32}$ Albert Hourani (1991),. P. 87. 
Sassanian Empire as a serious opponent right from the beginning of their relations. ${ }^{33}$

Even though the two had such a relationship, they not only kept relations in diplomacy and wars, but also in trade. ${ }^{34}$ At the beginning, as in the period of the Parthian Empire, the most important contacts were realized by the peoples of the Fertile Crescent. By the third century the principal inhabitants were either Aramaic, Syriac speakers (including Palmyrene, Hatran and other dialects) or Arabic speakers. ${ }^{35}$ However, gradually these trading states were absorbed by the Romans, with the Nabataean kingdom conquered by Trajan in 106, Edessa by Caracalla in 214 and finally Palmyra by Aurelian in 272; in the east, the Sassanians were taking the same actions: Spasinou Charax at the head of the Persian Gulf was conquered by Ardashir early in his reign, and the last of the 'caravan cities', Hatra, was taken by him at the end of his rule in $240 .^{36}$ The absorption of the trading states by the Romans and Sassanians led to their face to face confrontation, as well as to a decline in commerce.

This hostile situation exacerbated the difficulties of communication between them; for the Romans, more serious problem was that its commercial activities and access to luxury goods were cut off by the Sassanians. It is said that for rather selfish reasons the Sassanians permitted the neighboring peoples to engage in trade as they pleased; they made good profit from the exchange of these luxury goods, which included not only silk but also precious stones, spices, incense and ivory. ${ }^{37}$ For getting access to the eastern goods, in 298 and 408-409, the Roman Empire requested the Sassanian Empire to agree to open Nisibis, Callinicum, and Artashat as open ports for mutual trade, ${ }^{38}$ in particular for silk. In later times, more specific evidence that the Sassanian Empire restricted the access of the Roman Empire to oriental products can be found during the reign of the Justinian the Great. Until to the sixth century, the Sassanians and their kings controlled the intermediate territory of Mesopotamia between Byzantium and the East. Ruling from their Capital of Ctesiphon (now in Iraq), the Persians, under King Chosroes I, dominated most of Byzantium's southern access to silk trade through the Silk Road via the Persian Gulf and the Tigris-Euphrates watersheds. Procopius records that, in order to break this block, Justinian the Great "purposed that the Ethiopians, by purchasing silk from India and selling it among the

\footnotetext{
${ }^{33}$ Beate Dignas \& Engelbert Winter (2008), p. i.

${ }^{34}$ Beate Dignas \& Engelbert Winter (2008), pp. 2, 195.

${ }^{35}$ Richard N. Frye (2007), p. 473.

${ }^{36}$ Richard N. Frye (2007), pp. 472-473.

${ }^{37}$ Beate Dignas \& Engelbert Winter (2008), p. 195.

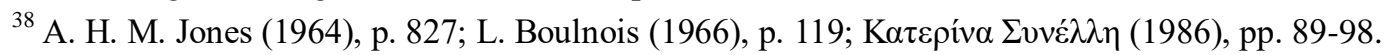


Romans, might themselves gain much money, while causing the Roman to profit in only one way, namely, that they no longer be compelled to pay over their money to their enemy". ${ }^{39}$ However, Justinian the Great did not succeed, since he underestimated the strength of the Persian grip. ${ }^{40}$ Procopius told us that the Sassanian traders completely dominated the Indian Ocean and were able to buy up all the silk arriving in Ceylon from further east; consequently, the Ethiopian traders were never able to buy directly from the exporters. ${ }^{41}$ Finally, the introduction of silkworms into the Roman Empire in the 550s and the alliance with the Sogdians and Turks broke the monopoly of the Sassanian Empire on silk, ${ }^{42}$ and relations between the two empires dealt mostly with diplomacy and military in the later period.

Relations between the Sassanian Empire and China before the fifth century were not as close as before, which was due to the ever-changing political condition of China. In the period from the third century to the sixth century, China was in an uncertain period with the frequent alteration in politics, culture, and ethnicity, as the result of which, China's communications with the Western Regions and further were often cut off constantly. After that, with the help of the Chinese sources, the first embassy from the Sassanian Empire sent to China happened in the Northern Wei court of China in 455, and afterward, another ten embassies from there to north China were recorded. ${ }^{43}$ In addition, through the archaeological excavations, a quite number of Sassanian silver coins have been found in north China. ${ }^{44}$ From the side of China, it is recorded that, in 468, envoys were sent by the Northern Wei of China to the court of the Sassanian Empire. ${ }^{45}$ In consideration of the evidence for both sides, it is clear that in fifth to sixth centuries, the Sassanian Empire and north China had very frequent economics and cultural communications. ${ }^{46}$ Zhang Xu-shan argues that, in this period, the Sassanian Empire initiated frequent embassies and tried to develop a relationship with China in order to form an alliance with them so as to better deal with the Hephthalites and the later Turks. ${ }^{47}$ Also, taking into account the Sassanians' control of the sale of Chinese silk to the Roman Empire, it can be induced that the commercial

\footnotetext{
${ }^{39}$ Procopius, Wars I. xx.9, Procopius (1954), p.193.

${ }^{40}$ Michael Maas (2005), p. 502.

${ }^{41}$ Procopius, Wars, I. xx.12, Procopius (1954), p. 193.

${ }^{4}$ Michael Maas (2005), p. 503; Xu-shan Zhang (2012), pp. 265-268; Stefanos Kordosis (2012), pp. 276-283.

${ }^{43}$ Xu-shan Zhang (2012), p. 272.

${ }^{44}$ According to the data, since the beginning of the 20th century, more than 1900 Sassanian silver coins have been found in China, see Li Sun (2004), pp. 35-54.

${ }^{45}$ Xu-shan Zhang (2012), pp. 271-272.

${ }^{46}$ Zhong-kun Wang (2003), p. 668.

${ }^{47}$ Ibid, pp. 272-273.
} 
profits and political intention are the two-fold reason for the Sassanians' constructing relations with China.

From the end of the sixth century to the fall of the Sassanian Empire, the Sassanians sent many times of envoys to China, especially when the Sassanians were under the threaten of the Arabs, three times of envoys were sent to Tang court of China for help, however, the request was not satisfied with the difficulties happened in China. ${ }^{48}$ In the middle of the seventh century, the Sassanian Empire was conquered by the Arabs, the inheritors of the empire escaped to China for protection, however, they never took back their power again, the relationship of China with the Persian Empire turned into that with the Arabs.

Generally, it can be concluded that during the first to the seventh century, the Persian Empires kept an opponent relationship with the Roman Empire, meanwhile, the trade activities also happened between them; the Persian Empires kept friendly relation with China, the interaction of trade and culture was the main theme between them. The main role of the Persian Empire in the relation of the Roman Empire and China was intermediary. The explanation for such kind of relationship and role should be the geo-political position of the Persian Empire and the benefits from the trade on the Silk Road.

\footnotetext{
${ }^{48}$ H. Yule, Cathay and the Way Thither, I, p.96.
} 


\section{Bibliography}

Arnaud, P. (1987). Les guerres des Parthes et de l'Arménie dans le première moitié du premier siècle av.n.è.: problèmes de chronologie et d'extension territoriale (95 B.C. - 70 B.C.). Mesopotamia, 22, 129 -145.

Bellina, Bérénice, \& Glover, Ian. (2004). The archaeology of early contact with India and the Mediterranean World, from the fourth century BC to the fourth century AD. In Ian Glover \& Peter Bellwood (Eds.), Southeast Asia: From Prehistory to History (pp. 68-87). Psychology Press.

Boulnois, L. (1966). The Silk Road. Trans. by Chamberlin, London.

Chavannes, E. (1907). Les Pays d'Occident d'après le Heou Han chou. T'oung Pao, $8,149-234$.

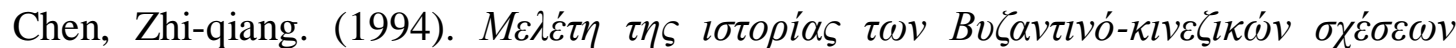

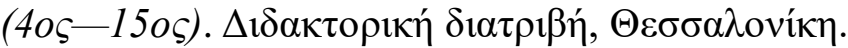

Chen, Zhi-qiang. (2004). The Sources of the Roman-Greek World in Ancient and

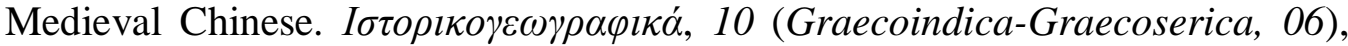
257-434.

Dignas, Beate, \& Winter, Engelbert. (2008). Rome and Persia in Late Antiquity: Neighbours and Rivals. New York: Cambridge University Press.

Fan, Ye. (2014). Hou Hanshu. Beijing: Zhonghua Book Company.

Frye, Richard N. (2007). Sassanians. In Alan K. Bowman, Peter Garnsey, \& Averil Cameron (eds.), The Cambridge Ancient History, Vol. XII, The Crisis of Empire, A. D. 193-337. Cambridge, UK: Cambridge University Press.

Gregoratti, Leonardo. (2015). The Parthian Empire: Romans, Jews, Greeks, Nomads, and Chinese on the Silk Road. In Mariko Namba Walter, James P. Ito-Adler (eds.), The Silk Road: Interwoven History, Vol. 1 Long-distance trade, Culture, and Society. Cambridge Institutes Press.

Haywood, John. (2000). Historical atlas of the classical world, $500 B C-A D 600$. Barnes \& Noble Books.

Hourani, Albert. (1991). A History of the Arab Peoples. London: Faber and Faber. 
Liu, Xin-ru. (2001). Migration and Settlement of the Yuezhi-Kushan: Interaction and Interdependence of Nomadic and Sedentary Societies. JWH, vol.12, no. 2, University of Hawaii Press, 261-292.

Jones, A. H. M. (1964, paper edition, 1986). The Later Roman Empire 284-602: A Social, Economic and Administrative Survey. 2 vols., Oxford.

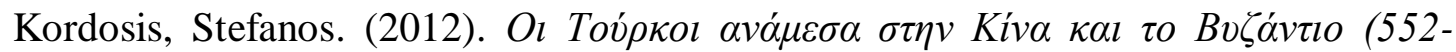

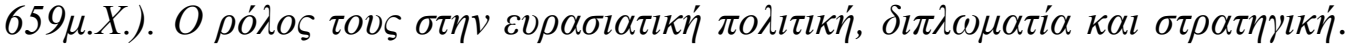

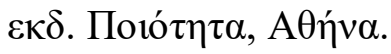

Leslie, D.D.-Gardiner, K.H.J. (1996). The Roman Empire in Chinese Sources. Rome: Bardi Editore.

Kordosis, Michael. (1991). China and the Greek World. An Introduction to GreekChinese Studies with Special Reference to the Chinese Sources. I. Hellenistic-

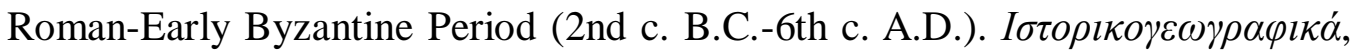
3 (Graecoindica-Graecoserica, 2), 143-253.

Maas, Michael. (2005). The Cambridge Companion to the Age of Justinian. New York: Cambridge University Press.

Meulen, W. J. van der. (1975). Ptolemy's Geography of Mainland Southeast Asia and Borneo. Indonesia, no.19, 1-32.

Pourshariati, Parvaneh. (2008). Decline and Fall of the Sasanian Empire: The Sasanian-Parthian Confederacy and the Arab Conquest of Iran. London: I. B. Tauris \& Co Ltd.

Procopius. (1954). Procopius. Edited by H. B. Dewing, Procopius, in seven volumes, I, History of the Wars, Books I and II. Loeb Classical Library. Cambridge, Mass.: Harvard University Press.

Rong, Xin-jiang, \& Wen, Xin. (2012). The Semantic Shift of "Western Region" and the Westward Extension of the "Border" in Tang Dynasty [Xiyu gainian de bianhua yu tangchao bianjing de xiyi: jiantan anxi duhufu zai tang zhengzhi tixi zhong de diwei]. Journal of Peking University (Philosophy and Social Sciences), vol. 49, no. 4, 113-119.

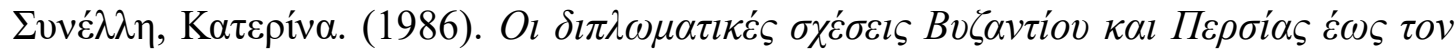

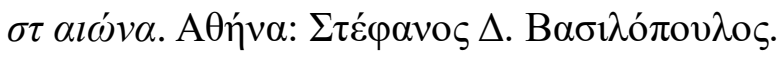


Sun, Li (2004). Distribution of the Sassanian Silver Coins and Their Functions in China. Acta Archaeologica Sinica, 35-54.

Thorley, J. (1971). The Silk Trade between China and the Roman Empire at its Height circa. AD 90-130. Greece and Rome Second Series, vol. 18, no. 1, 71-80.

Yarshater, E. (2006). The Seleucid, Parthian and Sasanian Periods. The Cambridge History of Iran (Vol. $3<1>$, <2>). Cambridge: Cambridge University Press.

Yule, H. (1915). Cathay and the Way Thither; Being a Collection of Medieval Notice of China, I, London.

Yu, Tai-shan. (2013). China and the Ancient Mediterranean World: A Survey of Ancient Chinese Sources [Gudai dizhonghai shiji he zhongguo guanxishi yanjiu]. Chinese edition, published by The Commercial Press (Beijing), 2012. The English edition published in Sino-Platonic Papers, no. 42, 2013.

Wang, Tao. (2007). Parthia in China: a Re-examination of the Historical Records. In Curtis, Vesta Sarkhosh and Sarah Stewart, The Age of the Parthians: The Ideas of Iran 2 (pp. 87-104). London \& New York: I.B. Tauris \& Co Ltd.

Wang, Zhong-kun. (2003). History of Wei-Jin, and South-North Dynasties [Weijin nanbeichao shi]. Shanghai: Shanghai People Publishing House.

Zhang, Xu-shan. (2005). Review on Study of Li-Kan and Ta-chin in a Hundred Years [Jinbainianlai Li-xuan, Daqin wenti yanjiuzongshu]. Trends of Recent Researches on the History of China, 03, 11-19.

Zhang, Xu-shan. (2012). A Study on Realations between China and the Byzantine Empire [Zhongguo yu baizhantingdiguo guanxi yanjiu]. Beijing: Zhonghua Book Company. 


\section{Appendix}

Fig. 1. Green Roman glass cup unearthed at Eastern Han Dynasty (25-220 AD) tomb, Guangxi, China.

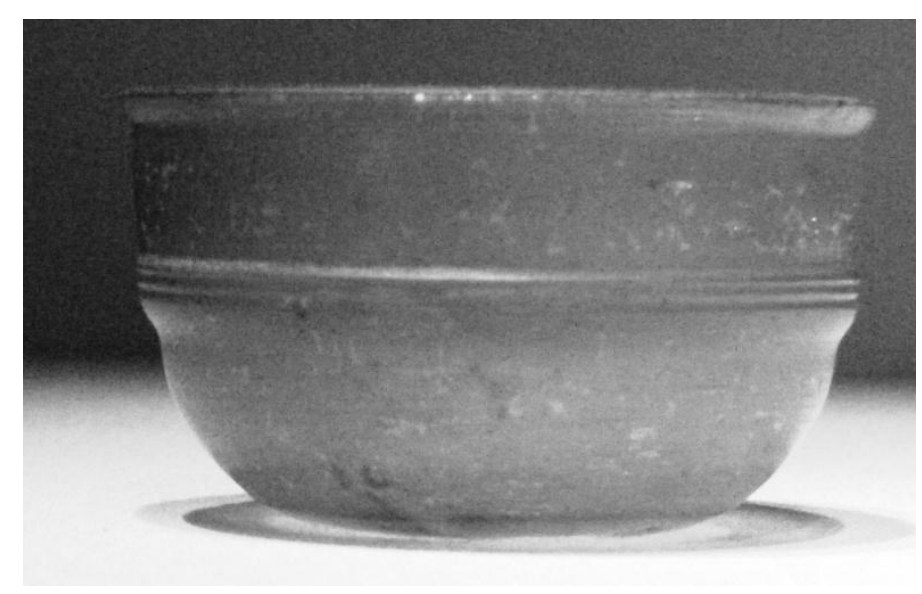

https://commons.wikimedia.org/wiki/File:Green_glass_Roman_cup_unearthed_at _Eastern_Han_tomb,_Guixian,_China.jpg accessed to 16-11-2015

Fig. 2. A Solidus of Anastasius I (491-518), in 2013, found in a tomb at the period of North Wei (386-534 AD), Luoyang, China.

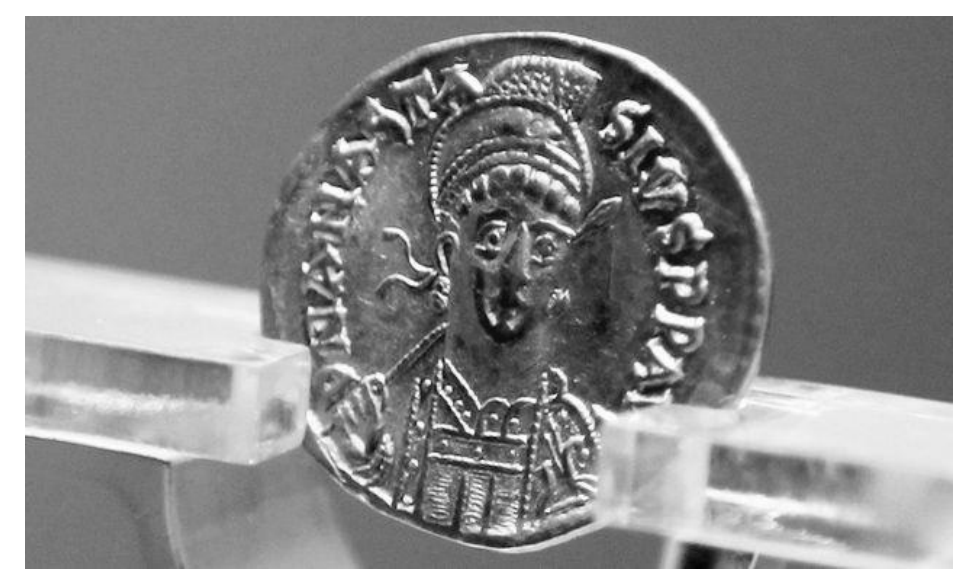

http://cn.blouinartinfo.com/news/story/977255/luo-yang-fa-xian-bai-zhan-ting-jinbi, accessed to 16-11-2015. 
Fig. 3. The Parthian Empire on the map in $200 \mathrm{AD}$

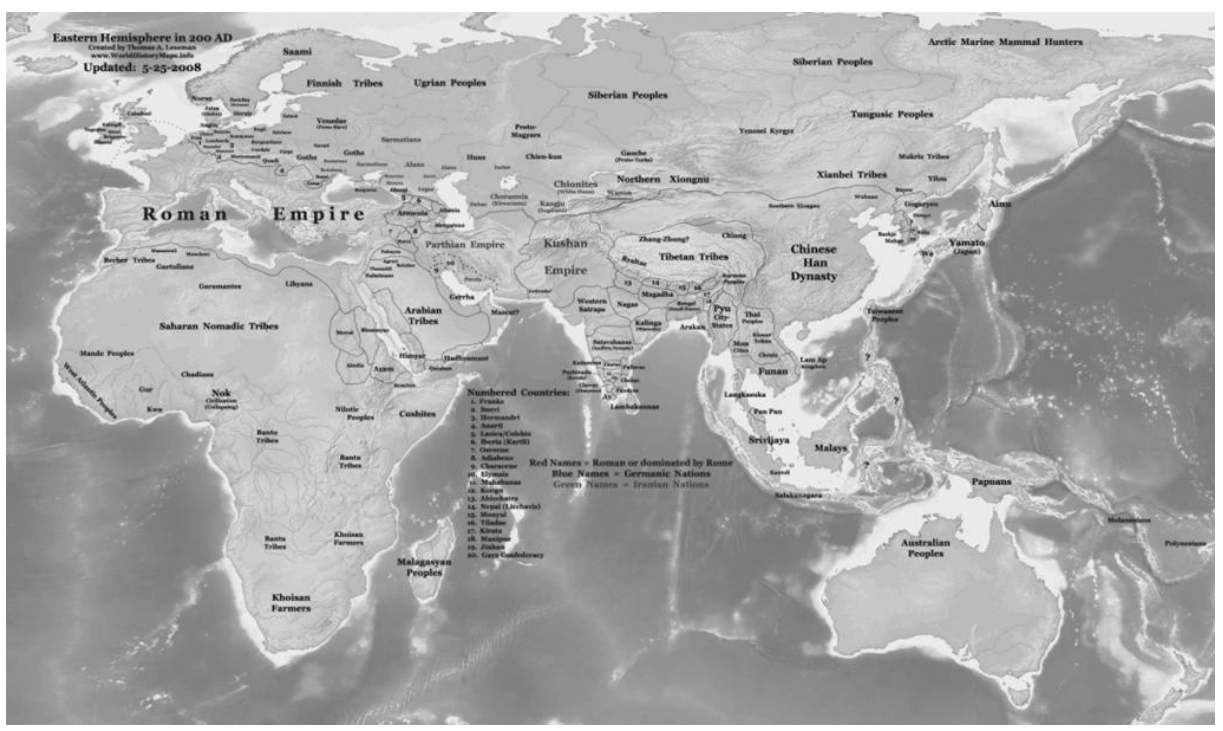

https://commons.wikimedia.org/wiki/File\%3AEast-Hem 200ad.jpg, accessed to 16-11-2015.

Fig. 4. The Sassanian Empire on the map in 600AD

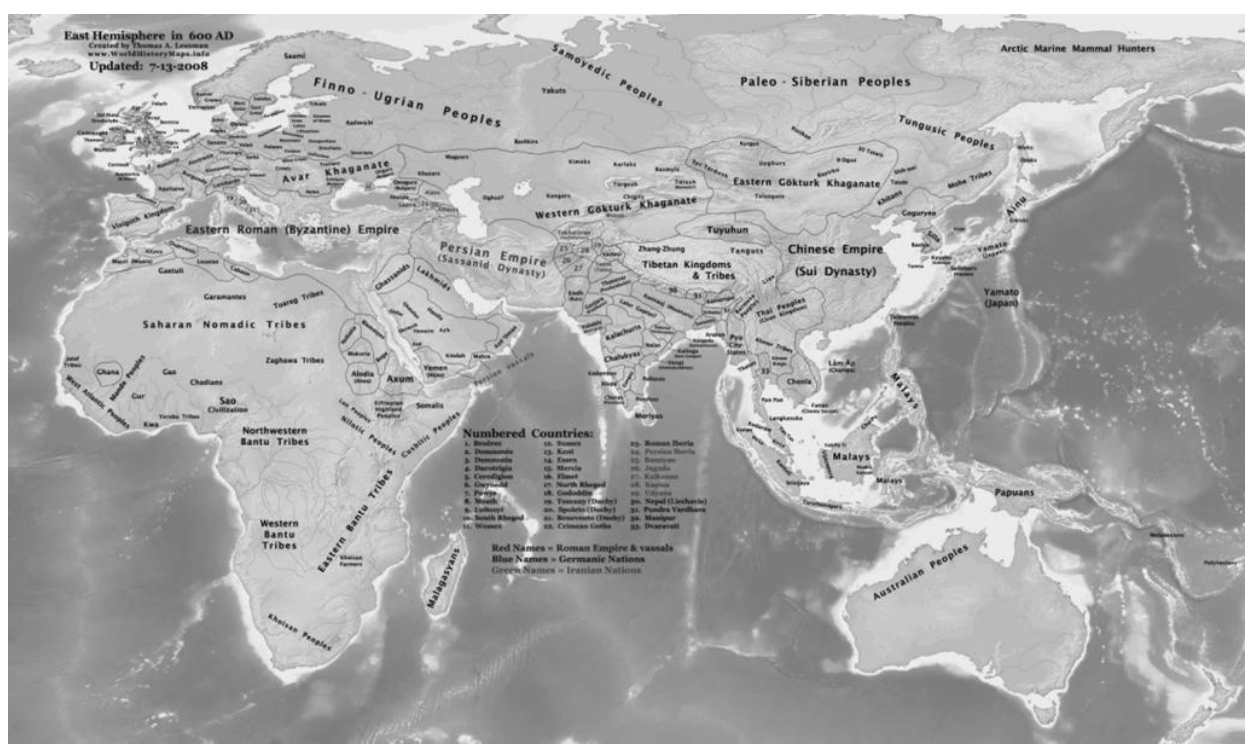

https://commons.wikimedia.org/wiki/File:East-Hem 600ad.jpg, accessed to 16-112015. 